\title{
ErbB2 signaling at the crossing between heart failure and cancer
}

\author{
Zarha Vermeulen $^{1} \cdot$ Vincent F. M. Segers $^{1,2} \cdot$ Gilles W. De Keulenaer ${ }^{1,3}$
}

Received: 3 June 2016/Accepted: 8 August 2016/Published online: 5 September 2016

(c) The Author(s) 2016. This article is published with open access at Springerlink.com

\begin{abstract}
The dual role of ErbB2 (or HER-2) in tumor growth and in physiological adaptive reactions of the heart positions ErbB2 at the intersection between cancer and chronic heart failure. Accordingly, ErbB2-targeted inhibitory therapy of cancer may lead to ventricular dysfunction, and activation of ErbB2 for heart failure therapy may induce malignancy. The molecular processes leading to the activation of ErbB2 in tumors and cardiac cells are, however, fundamentally different from each other. Thus, it must be feasible to design drugs that specifically target either physiological or malignant ErbB2 signaling, to activate ErbB2 signaling in heart failure with no increased risk for cancer, and to inhibit ErbB2 signaling in cancer with no increased risk for heart failure. In this review, we present a state-of-the-art on how ErbB2 is regulated in physiological conditions and in tumor cells and how this knowledge translates into smart drug design. This leads to a new generation of drugs interfering with ErbB2 in a unique way tailored for a specific clinical goal. These exciting developments at the crossing between cancer and heart failure are an elegant example of interdisciplinary collaborations between clinicians, physiologists, pharmacologists, and molecular biologists.
\end{abstract}

Gilles W. De Keulenaer

gilles.dekeulenaer@uantwerpen.be

1 Laboratory of Physiopharmacology, University of Antwerp, Universiteitsplein 1, 2610 Antwerp, Belgium

2 Department of Cardiology, University Hospital Antwerp, Wilrijkstraat 10, 2650 Edegem, Belgium

3 Department of Cardiology, Middelheim Hospital, Lindendreef 1, 2020 Antwerp, Belgium
Keywords Neuregulin-1 - ErbB2 signaling · Cardiotoxicity

\section{Introduction}

The ErbB2 (or HER2) receptor is overexpressed in $25 \%$ of breast tumors and is a major drug target in cancer therapy. Trastuzumab $\left(\right.$ Herceptin $^{\circledR}$ ) was the first anti-ErbB2 drug to be approved by the FDA. Unexpectedly, patients receiving trastuzumab were found to have a high incidence of heart failure, especially when combined with anthracyclines. This observation led to the discovery of the protective ErbB/NRG-1 system in cardiovascular physiology. The combined role of ErbB2 in malignant tumor growth, and in compensatory processes in the heart, positions ErbB2 at the crossing between cancer and heart failure. Hence, pharmacological inhibition of ErbB2 to treat cancer may induce heart failure, while systemic activation of ErbB2 to treat heart failure may induce malignancy. ErbB2 belongs to the family of human epidermal growth factor (EGF) receptors consisting of EGFR (ErbB1), ErbB2, ErbB3, and ErbB4 (Fig. 1). As opposed to its family members, ErbB2 has no known ligand, instead, it has a permanent open confirmation, continuously exposing a dimerization arm for interaction with another ErbB family member (heterotypic ErbB signaling). ErbB3 is a kinase-impaired receptor and requires another dimerization partner for activation.

Despite this general theme, the principles of ErbB2 signaling in physiological conditions, including the regulation of cardiac function, are fundamentally different from those in cancer cells [10]. This suggests that it must be feasible to specifically interfere with either physiological or oncogenic ErbB2 signaling, to activate ErbB2 signaling in heart failure with no increased risk for cancer on the one 
Fig. 1 ErbB receptors. Human epidermal growth factor receptors consist of EGFR (ErbB1), ErbB2, ErbB3, and ErbB4. ErbB receptors share high homology in the extracellular domain and the kinase domain. However, ErbB3 lacks tyrosine kinase activity and ErbB2 has no known ligand, instead, it has a constitutive open conformation, continuously exposing a dimerization arm for interaction with another ErbB family member. NRG-1, secreted from cardiac endothelial cells, can bind to ErbB3 and ErbB4

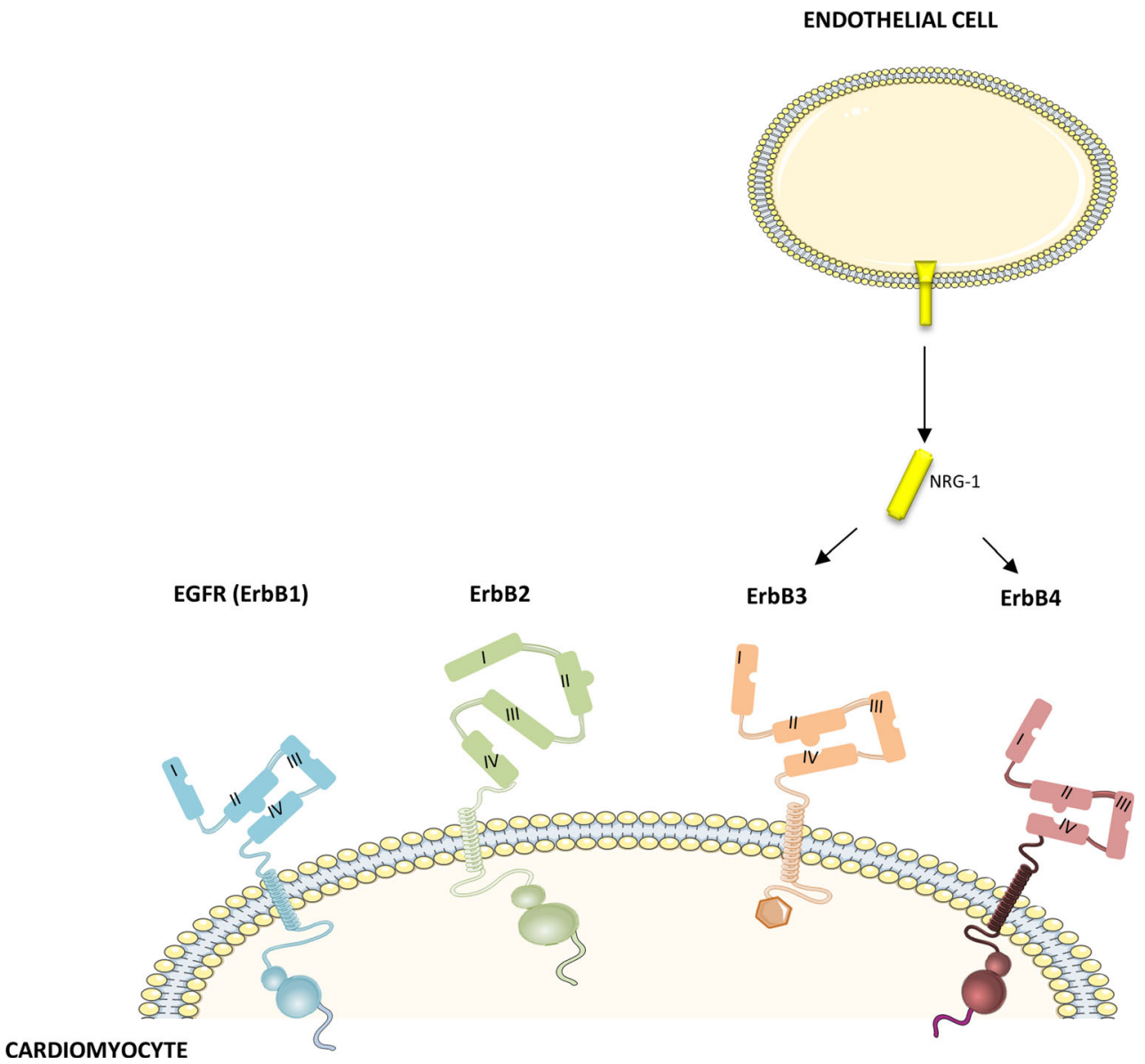

hand, and to inhibit ErbB2 signaling in cancer with no increased risk for heart failure on the other hand. Smart drug design developed in a stepwise fashion has now provided at least seven different anti-ErbB2 cancer drugs, together with a few molecules to activate physiological ErbB2 signaling for the treatment of heart failure. Each of these drugs interferes with ErbB2 in a unique way. In this review, we present a comprehensive overview of these developments at the crossing between cancer and heart failure. We will address the biology of ErbB signaling in cancer and cardiac cells, the regulatory aspects and clinical benefits of NRG-1/ErbB signaling activation in heart failure, and the working mechanisms of different anti-ErbB2 drugs and their degree of cardiotoxicity.

\section{ErbB2 signaling in the heart}

Myocardial ErbB2 signaling is elementary during fetal development, adaptation, and, perhaps, even regeneration of the heart [9, 31, 41]. In adult life, myocardial ErbB2 is part of an endothelium-controlled NRG-1/ErbB signaling axis, in which NRG-1, secreted from cardiac endothelial cells, binds to ErbB4 and/or ErbB3 in the myocardial tissue $[6,10]$. In neonatal hearts, ErbB2 and ErbB4 are highly expressed, but they progressively decrease 1 week after birth. ErbB3 expression is more stable, and may even be higher throughout the postnatal development [6, 9]. Although NRG-1 signaling has generally been attributed to signaling effects mediated by ErbB4, recent data suggest that ErbB3 cannot be ignored [61]. As opposed to ErbB4, however, ErbB3 cannot signal through homodimers and always requires another ErbB dimerization partner to initiate intracellular signaling.

Following binding of ErbB4 to NRG-1, ErbB4 undergoes a conformation switch from a closed conformation to an open conformation, exposure of a dimerization arm in subdomain II, formation of ErbB4/ErbB2 heterodimers, increased ErbB4/ErbB2 tyrosine kinase activity, and transphosphorylation of the ErbB cytoplasmic signaling tails (Fig. 2a). Although ErbB2 is the preferred dimerization partner of ligand-activated ErbB4, NRG-1 may also induce the formation of ErbB4 homodimers (homotypic ErbB signaling) or ErbB4/ErbB3 heterodimers, and has such signal in an ErbB2-independent way. The relative contribution between both homotypic and heterotypic signaling by NRG-1 is unknown. It is also not known whether the relative contribution of homo- and heterodimer signaling and the ratio between ErbB2, ErbB3, and ErbB4 may 


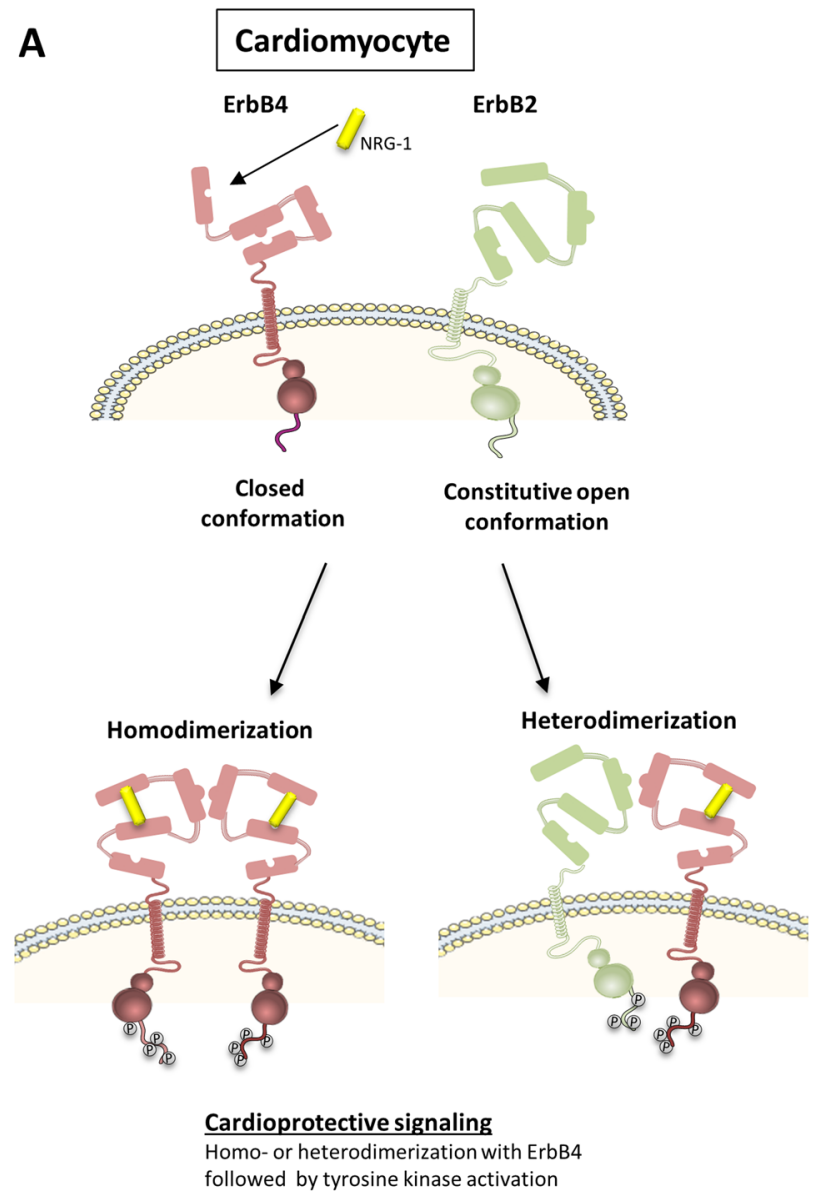

Fig. 2 ErbB signaling in ErbB2-overexpressing breast cancer cells and in cardiomyocytes. a In adult cardiomyocytes, NRG-1 binding to ErbB4 induces a switch from a closed to the open receptor conformation, exposing a dimerization arm (domain II). Ligandactivated ErbB4 results in the formation of either ErbB2/ErbB4 heterodimers or ErbB4/ErbB4 homodimers. This leads to the phosphorylation of specific tyrosines in the tail region, and the

change in certain conditions. As further explained below, experiments with bivalent NRG-1 have shown that homotypic NRG-1 signaling (through ErbB4/ErbB4 homodimers) may be sufficient for cardioprotection [27]. Receptor homo- or heterodimerization triggers the activation of signaling pathways, such as the phosphoinositide 3-kinase (PI3K)/Akt, Ras/Extracellular signal-regulated kinases (ERK), and proto-oncogene tyrosine-protein kinase (Src)/focal adhesion kinase (FAK) pathway. NRG-1/ErbB signaling protects cardiomyocytes from apoptosis and stimulates NO production through PI3K/Akt signaling. It also induces cardiomyocyte growth and proliferation through both PI3K/Akt and ERK1/2 signaling (Fig. 3a) [47].

The NRG-1/ErbB signaling axis is activated in heart failure, and compensates for maladaptive processes that lead to the progression of cardiac dysfunction, at least during the early stages of the syndrome [30,31]. Recently, D'Uva et al.
B

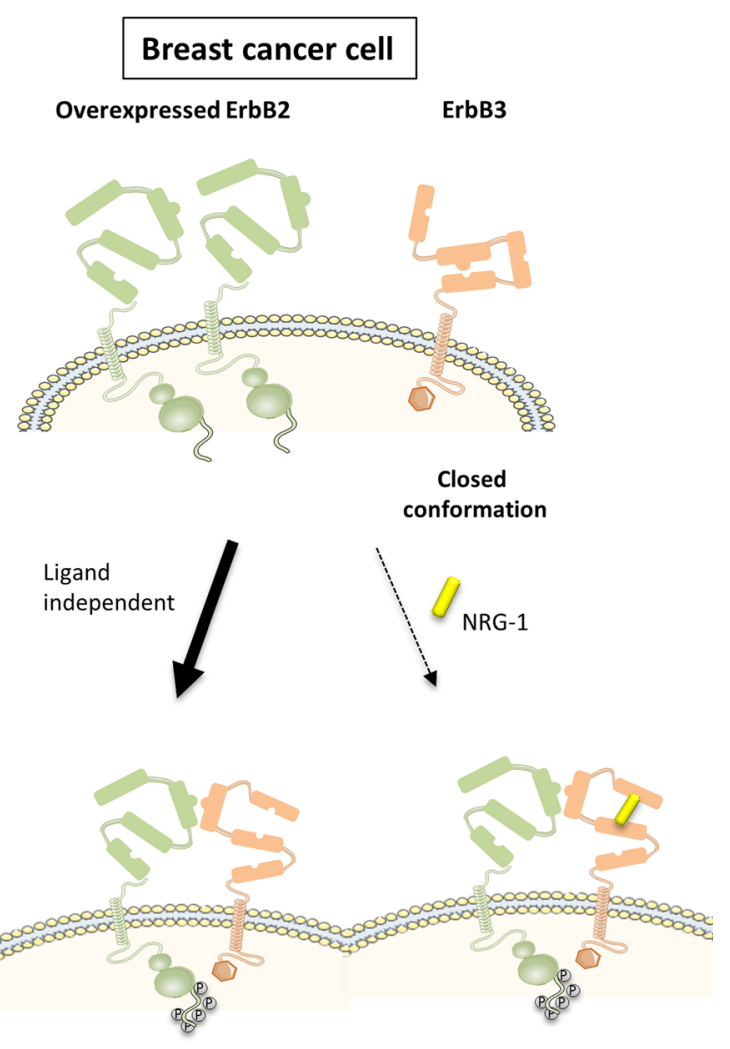

Pro-neoplastic signaling

Overexpressed ErbB2 or heterodimization with ErbB3 followed by tyrosine kinase activation

activation of downstream proteins and cardioprotective signaling cascades. b Oncogenic signaling in breast cancer cells can be mediated by overexpressed ErbB2. Amplified ErbB2 triggers predominantly ligand-independent oncogenic ErbB2/ErbB3 heterodimers. This leads to the phosphorylation of specific tyrosines in the tail region of the receptors, and the activation of downstream proteins and pro-neoplastic signaling

showed that the mechanism of ErbB2-mediated cardioprotection may be subdivided into regeneration by increased cardiomyocyte dedifferentiation and proliferation (which was ERK-dependent), and the induction of hypertrophy and cell survival (which is both Akt- and ERK-dependent) [9]. They also showed that transient reactivation of ErbB2 signaling after myocardial infarction promotes heart regeneration, which after ErbB2 signaling termination, resulted into cardiomyocyte redifferentiation and tissue replacement with reduced scarring [9]. This study suggests that tuning ErbB signaling in the correct way could provide an optimal route for maximizing endogenous regeneration capacity of the injured adult heart. Of note, Kühn et al. demonstrated that these regenerative effects of NRG-1 are more pronounced during the neonatal period than in adulthood [44]. Interestingly, another series of recent experiments indicate that, apart from healing the heart, the activation of ErbB signaling with systemic NRG-1 may also mitigate common co- 
A

$$
\text { Cardioprotective signaling }
$$

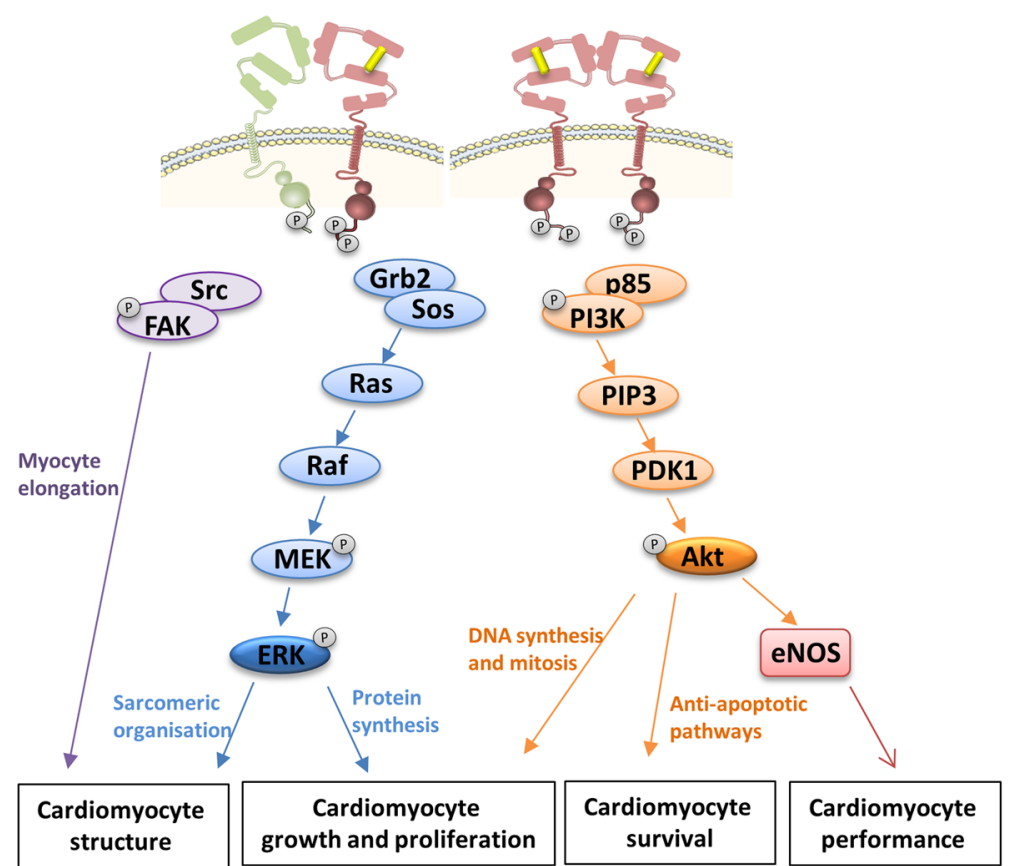

Oncogenic signaling

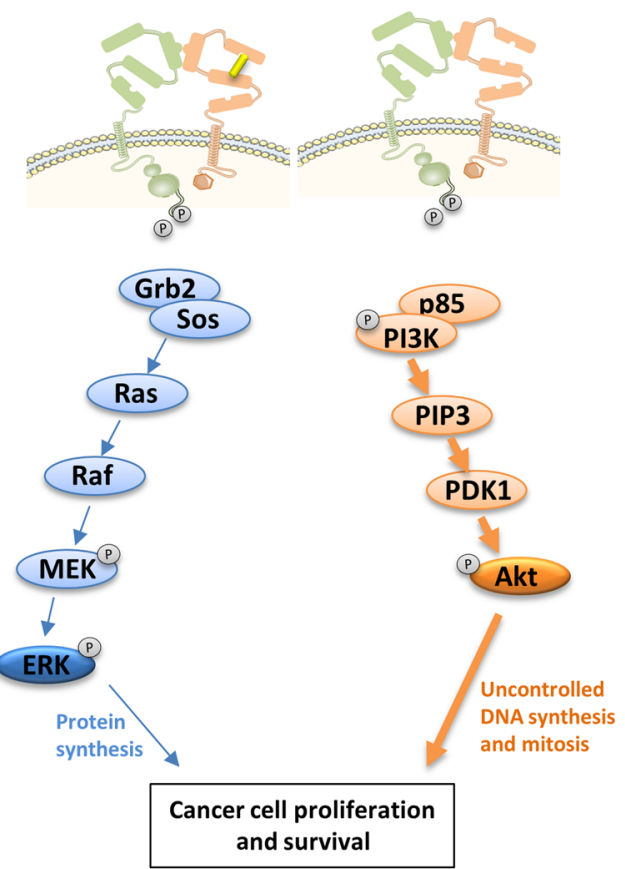

Fig. 3 Intracellular signaling cascades following the activation of ErbB receptors in cardiomyocytes and cancer cells. a ErbB receptor homo- or heterodimerization in cardiomyocytes triggers the activation of Ras/ERK, PI3K/Akt and Src/FAK signaling pathways. NRG-1/ ErbB signaling in cardiomyocytes regulates structure, function, growth, proliferation and survival [1, 39]. b Oncogenic signaling through ErbB2 homodimers or ErbB2-ErbB3 heterodimers induces the activation of Ras/ERK and PI3K/Akt signaling pathways. PI3K/

morbidities of heart failure, including diabetes, atherosclerosis, pulmonary hypertension, and renal dysfunction $[12,40,56,59]$. These effects are most likely mediated by acting on local tissue ErbB receptors in the liver, skeletal muscle cells, kidney cells, and vascular cells $[42,56]$. Accordingly, apart from its effects on the failing heart, NRG1 may have pleiotropic actions in several organs and pathophysiological processes throughout the organism. If confirmed in humans, on top of the standard therapy, NRG-1 treatment may take a particular position in the pharmacological therapy of heart failure aimed at regenerating the injured heart and mitigating its co-morbidities. NRG-1 has been used in many animal models of heart failure and is currently tested in phase III clinical trial in heart failure with a reduced left ventricular ejection fraction (Table 1-2) [41]. In these trials, NRG-1 is administrated as EGF-domain fragment of recombinant human (rh)NRG- $1 \beta$ or as an Ig domain-containing version of NRG-1 $\beta$ known as glial growth factor 2 (GGF2), usually by intravenous infusions.

A concern during pharmacological ErbB signaling activation in heart failure is, however, a potential stimulation of tumor growth. As explained below, tumor growth
Akt signaling has a central oncogenic role as its robust activation induces intense cell growth and proliferation [55]. Src proto-oncogene tyrosine-protein kinase, $F A K$ focal adhesion kinase, Grb2 Growth factor receptor-bound protei-2, Sos Son of sevenless, $M E K$ mitogenactivated ERK kinase, ERK extracellular signal-regulated kinase, PI3K phosphatidyl inositol-3 kinase, PIP3 phosphatidyl inositol (4,5,6)-triphosphate, $P D K 1$ phosphoinositide dependent protein kinase-1, Akt protein kinase B, eNOS endothelial nitric oxide synthase

in ErbB2-amplified cells mainly results from the ligandindependent formation of ErbB2/ErbB3 oncogenic complexes. Therefore, at first glance, NRG-1 should not induce oncogenic complexes, and the risk to induce malignancy should be limited. However, NRG-1 also binds to ErbB3 on cancer cells forcing it to the "open conformation" and favoring formation of new oncogenic complexes. In this scenario, NRG-1 may advance tumor growth and/or promote tumor resistance during treatment with anti-ErbB2 therapies. A recent study contradicts this hypothesis. Ganapathy et al. demonstrated that rhNRG-1 administration in the first month of life, sufficient for stimulating cardiac regeneration, did not induce unwanted extra-cardiac neoplastic growth or the early stage neoplastic foci within 6 months [16].

\section{Smart drug design to activate ErbB signaling without inducing cancer}

In an attempt to design a translationally relevant ErbB agonist for the treatment of chronic diseases, such as heart failure, Griffith and Lee created bivalent NRG-1 $\beta$ 
Table 1 Administration of rhNRG-1 in animal models of heart failure

\begin{tabular}{|c|c|c|c|}
\hline Model & Species & RhNRG-1 treatment & Outcome \\
\hline MI [37] & Rat & $\begin{array}{l}10 \mu \mathrm{g} / \mathrm{kg} \text { day i.v. for } 5 \text { or } 10 \text { days, } \\
1 \text { week or } 2 \text { months } \\
\text { after LAD ligation }\end{array}$ & $\begin{array}{l}\text { Improved LV structure and dysfunction } \\
\text { Increased angiogenesis } \\
\text { Improved survival }\end{array}$ \\
\hline MI [2] & Mouse & $\begin{array}{l}2.5 \mu \mathrm{g} / \text { mouse i.p. for } 12 \text { weeks, } \\
1 \text { week after LAD }\end{array}$ & $\begin{array}{l}\text { Improved LV structure and dysfunction } \\
\text { Increased myocardial regeneration }\end{array}$ \\
\hline MI [19] & Rat & $\begin{array}{l}5 \mu \mathrm{g} / \mathrm{kg} \text { h i.v. for } 7 \text { days, } \\
8 \text { weeks after LAD ligation }\end{array}$ & Improved LV structure and dysfunction \\
\hline MI [20] & Rat & $\begin{array}{l}10 \mu \mathrm{g} / \mathrm{kg} \text { day i.v. for } 10 \text { days, } \\
4 \text { weeks after LAD ligation }\end{array}$ & $\begin{array}{l}\text { Improved LV structure and dysfunction } \\
\text { Decreased mitochondrial dysfunction } \\
\text { Decreased apoptosis } \\
\text { Decreased oxidative stress }\end{array}$ \\
\hline MI [58] & Rat & $\begin{array}{l}\text { Infarcted area injected with rhNRG-1 } \\
\text { carrying lentivirus }\end{array}$ & $\begin{array}{l}\text { Decreased apoptosis } \\
\text { Increased angiogenesis }\end{array}$ \\
\hline MI [15] & Swine & $\begin{array}{l}0.67 \mathrm{mg} / \mathrm{kg} \text { i.v. every } 2 \text { days for } \\
4 \text { weeks, } 1 \text { week after MI }\end{array}$ & $\begin{array}{l}\text { Improved LV dysfunction } \\
\text { Decreased fibrosis }\end{array}$ \\
\hline $\mathrm{I} / \mathrm{R}[13]$ & Rat & $\begin{array}{l}1,2,4 \text { or } 8 \mu \mathrm{g} / \mathrm{kg} \text { i.v. for } 20 \mathrm{~min} \text { prior } \\
\text { to } \mathrm{I} / \mathrm{R}\end{array}$ & $\begin{array}{l}\text { Improved LV structure } \\
\text { Decreased apoptosis } \\
\text { Decreased infarct size }\end{array}$ \\
\hline Myo-carditis [37] & Mouse & $30 \mu \mathrm{g} / \mathrm{kg}$ day i.v. for 5 days & $\begin{array}{l}\text { Improved LV structure and dysfunction } \\
\text { Decreased necrosis } \\
\text { Improved survival }\end{array}$ \\
\hline Doxo-induced CM [37] & Rat & $\begin{array}{l}20 \mu \mathrm{g} / \mathrm{kg} \text {.day i.v. for } 5 \text { days, } 4 \text { weeks } \\
\text { after first doxorubicin administration }\end{array}$ & $\begin{array}{l}\text { Improved LV structure and dysfunction } \\
\text { Decreased necrosis } \\
\text { Improved survival }\end{array}$ \\
\hline Doxo-induced CM [3] & Mouse & $\begin{array}{l}0.75 \mathrm{mg} / \mathrm{kg} \text { day s.c. for } 3-5 \text { days, } \\
1 \text { day before doxo administration }\end{array}$ & $\begin{array}{l}\text { Improved LV structure and dysfunction } \\
\text { Improved survival } \\
\text { Decreased apoptosis } \\
\text { Preserved cardiac troponins }\end{array}$ \\
\hline Pacing-induced CM [37] & Dog & $\begin{array}{l}3 \mu \mathrm{g} / \mathrm{kg} \text { day i.v. for } 5 \text { days } \\
\text { with continuous pacing, } 3 \text { weeks after } \\
\text { starting rapid pacing }\end{array}$ & Improved LV dysfunction \\
\hline Pacing-induced CM [34] & Rhesus monkey & $3 \mu \mathrm{g} / \mathrm{kg}$ day i.v. for 10 days & $\begin{array}{l}\text { Improved LV dysfunction } \\
\text { Increased myosin heavy chain } \alpha\end{array}$ \\
\hline Type 1 DCM [33] & Mouse & $\begin{array}{l}10 \mu \mathrm{g} / \mathrm{kg} \text { i.v. every } 2 \text { days for } \\
2 \text { weeks, } 12 \text { weeks after STZ } \\
\text { injection }\end{array}$ & $\begin{array}{l}\text { Improved LV structure and dysfunction } \\
\text { Decreased apoptosis } \\
\text { Decreased fibrosis }\end{array}$ \\
\hline
\end{tabular}

RhNRG-1 Recombinant human neuregulin-1, MI Myocardial infarction, I.v. Intravenous, LAD Left anterior descending artery, $L V$ Left ventricle, I.p., Intraperitonea, I/R Ischemia/Reperfusion, Doxo Doxorubicin, S.c. Subcutaneous, CM Cardiomyopathy, DCM Diabetic cardiomyopathy, STZ Streptozotocin

(NN) $[26,27]$. NN is a ligand for both ErbB3 and ErbB4 and drives particular homotypic interactions at the expense of others. This alters signaling and phenotypic outcomes compared with their native, monovalent counterparts. In cardiac cells, $\mathrm{NN}$ will predominantly promote the homotypic association of ErbB4, thereby reducing signaling through ErbB2/ErbB4 heterodimers (Fig. 4a). In tumor cells, NN drives a stable, homotypic association of ErbB3, which traps ErbB3, keeping it away from undesirable oncogenic signaling with ErbB2. ErbB3 has a weak kinase activity, and hence, ErbB3 homodimers are incapable of activating downstream signaling pathways (Fig. 4b). Consistently, NN induced anti-neoplastic or cytostatic responses in cancer cells [27]. The differences between the action of monovalent NRG-1 and bivalent NN are summarized in Table 3. Subsequent studies showed that NN significantly attenuated doxorubicin-induced cardiac dysfunction, 
Table 2 Clinical trials with rhNRG-1 as a therapy for heart failure

\begin{tabular}{lll}
\hline Description & Dosage & Outcome \\
\hline $\begin{array}{l}\text { Phase II, randomized, double-blind, } \\
\text { multicenter, background-therapy-based, } \\
\text { placebo-controlled, parallel group study }\end{array}$ & $\begin{array}{c}0.3,0.6 \text { or } 1.2 \mu \mathrm{g} / \mathrm{kg} 10 \\
\text { h i.v. infusion, } 10 \text { consecutive days }\end{array}$ & $\begin{array}{c}\text { Improved and sustained LVEF \% and } \\
\text { decreased LVEDV and LVESV at } 30 \\
\text { and } 90 \text { days after treatment }\end{array}$ \\
$\begin{array}{l}\text { S17] } \\
\text { Single-center, prospective, non- } \\
\text { randomized, open label study [25] }\end{array}$ & $\begin{array}{l}\text { Initial dose of } 1.2 \mu \mathrm{g} / \mathrm{kg} \text { for } 6 \mathrm{~h} \\
\text { Acute increase in CO }\end{array}$ \\
& $\begin{array}{c}0.6,1.2 \text { or } 2.4 \mu \mathrm{g} / \mathrm{kg} \text { for } 12 \mathrm{~h} \text { i.v. } \\
\text { infusion, } 10 \text { consecutive days }\end{array}$ & Improvement in LVEF
\end{tabular}

I.v. Intravenous, $L V E F \% \%$ Left ventricle ejection fraction, $L V E D V$ Left ventricle end-diastolic volume, LVESV Left ventricle end-systolic volum, $C O$ Cardiac output

Fig. 4 Effect of bivalent NRG$1 \beta(\mathrm{NN})$ in ErbB2overexpressing breast cancer cells and cardiomyocytes. a In cardiac cells, $\mathrm{NN}$ will predominantly promote homotypic association of ErbB4, but signaling through ErbB2/ErbB4 heterodimers will be reduced. ErbB4 homotypic signaling seems to be sufficient for cardioprotective signaling. b In tumor cells, NN drives a stable, homotypic association of ErbB3, which traps ErbB3, keeping it away from undesirable oncogenic signaling with ErbB2. ErbB3 has a weak kinase activity, and hence, ErbB3 homodimers are incapable of activating downstream signaling pathways. Consistently, NN induces anti-neoplastic or cytostatic responses in cancer cells
A

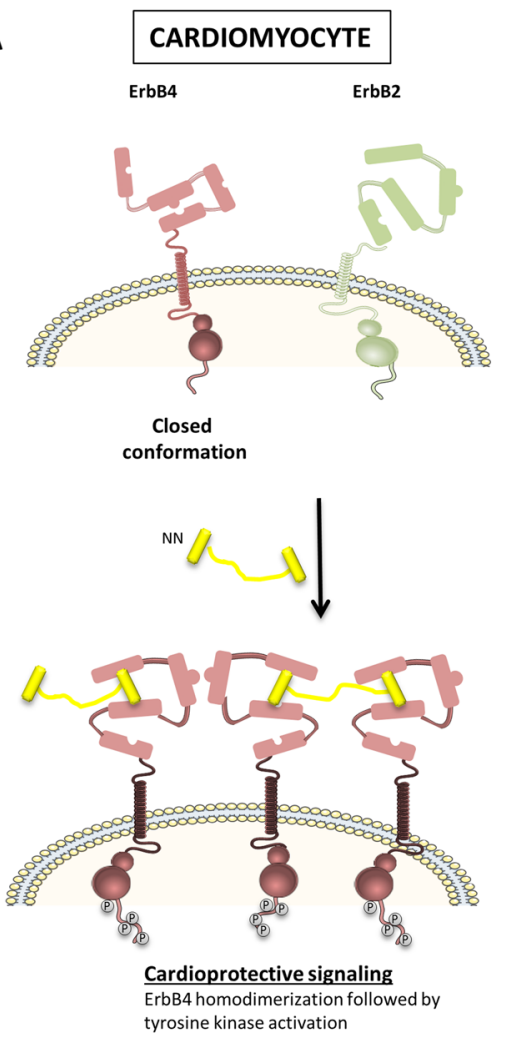

B
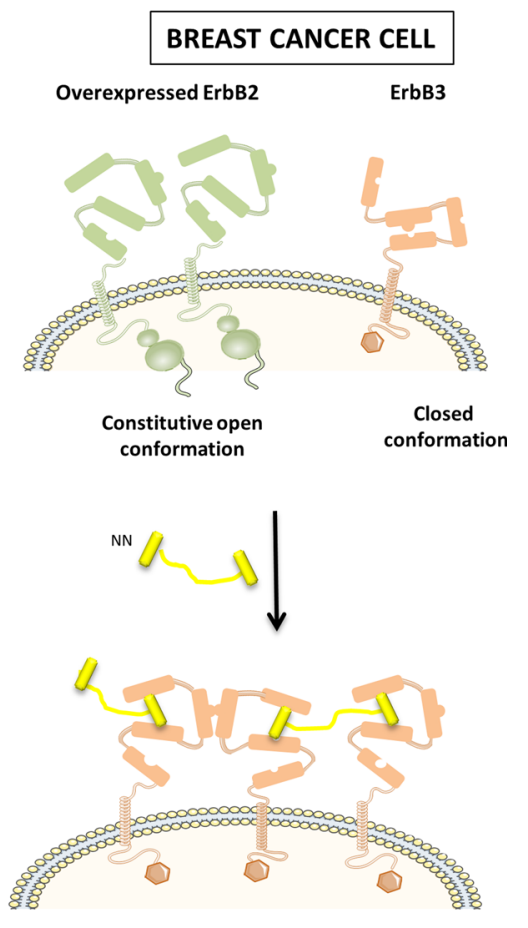

Cytostatic/Anti-neoplastic signaling ErbB3 homodimerization - very weak or inactive kinase

Table 3 Differences in the mechanism of monovalent NRG-1 compared with bivalent NRG-1

\begin{tabular}{lcc}
\hline Drug & Tumor cell & Cardiomyocyte \\
\hline Neuregulin-1 (NRG-1) & $\begin{array}{c}\text { NRG-1 stimulation may increase malignant } \\
\text { potential of ErbB2-expressing cancer cells by } \\
\text { inducing ErbB2 and ErbB3 heterotypic, pro- } \\
\text { neoplastic interactions }\end{array}$ & $\begin{array}{c}\text { NRG-1 is cardioprotective by inducing ErbB2/ } \\
\text { Erbb4 heterotypic and ErbB4/ErbB4 } \\
\text { homotypic interactions }\end{array}$ \\
BN decreases migration, inhibits proliferation \\
and increases apoptosis in ErbB2-expressing \\
cancer cells by trapping ErbB3 for homotypic, \\
weak/non-signaling interactions
\end{tabular}


indicating that ErbB4 homodimer signaling suffices for cardioprotection or, alternatively, that there remains enough ErbB2/ErbB4 signaling for a normal activity [27].

Accordingly, given the reduced pro-neoplastic potential of NN versus rhNRG-1, NN has translational potential for the treatment of chronic diseases, such as heart failure, with no increased risk to induce cancer.

\section{ErbB2 signaling in cancer}

In many different cancer cells, ErbB2 is amplified by increased gene transcription. Tumor growth is critically dependent on ErbB2 amplification, a process coined oncogenic addiction of malignancy. Amplified ErbB2 can bind to ErbB3 in an uncontrolled and at least partially ligand-independent way, forming an oncogenic ErbB2/ ErbB3 complex (Fig. 2b) [22]. In this complex, following phosphorylation of ErbB3 tyrosine residues by the ErbB2 kinase, ErbB3 interacts with the regulatory p85 subunit of PI3K without requirement of any adaptor proteins [46].
This results in the robust activation of the PI3K/Akt pathway and intense cell growth and proliferation, positioning ErbB3 as the key node in oncogenic ErbB2 signaling (Fig. 3b). This scenario is identified in $20-30 \%$ of invasive breast carcinomas, and in significant cases of ovarian, gastric, and bladder cancer.

ErbB2 has been the main therapeutic target within the ErbB2/ErbB3 oncogenic unit. The goal of ErbB2-targeted therapy is to interrupt PI3K/Akt signaling to stop cell proliferation and induce cell apoptosis. Clinical introduction of this strategy with the humanized anti-ErbB2 antibody trastuzumab $\left(\right.$ Herceptin $^{\circledR}$ ) has been successful, but chronic treatment has been disturbed by unforeseen problems, namely, (a) the development of tumor drug resistance and (b) the induction of cardiac dysfunction and heart failure [23]. These drawbacks have forced the design of newer anti-ErbB2 drugs.

A first challenge has been to intercept biological escape routes leading to anti-ErbB2 drug resistance. Recent evidence suggests that the upregulation of ErbB3 is critically involved in the process [51]. ErbB3 mRNA transcription is

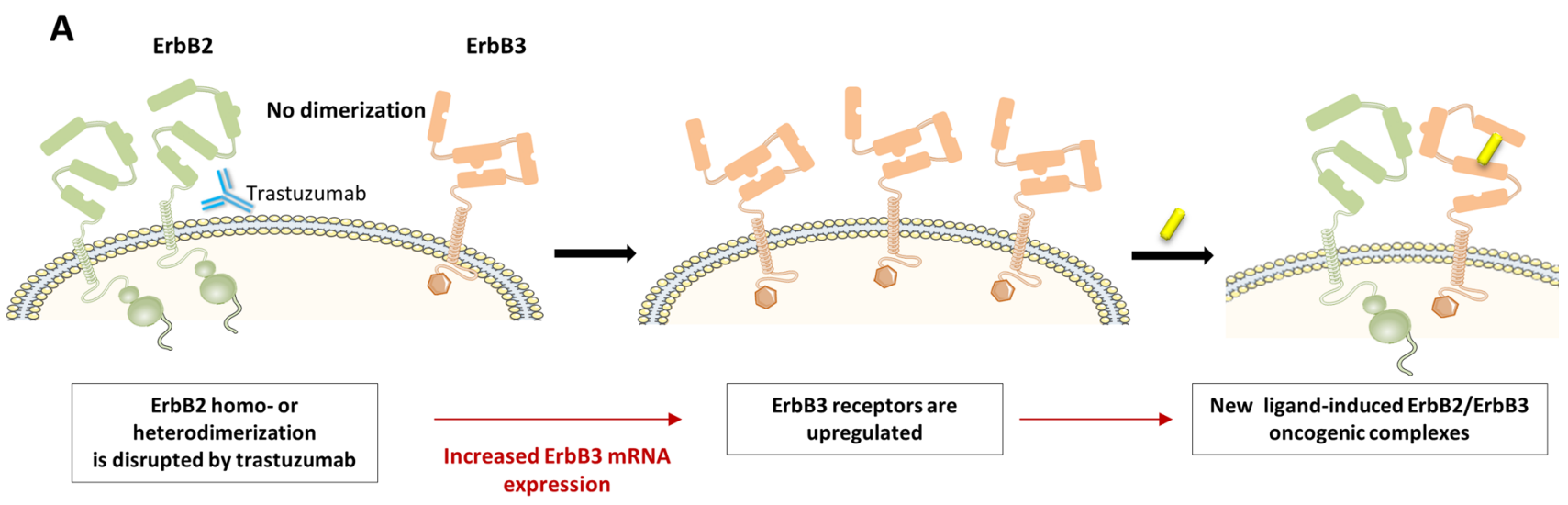

B

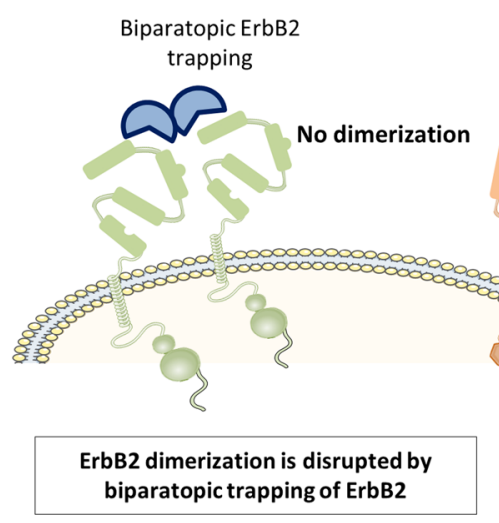

Fig. 5 Trastuzumab resistance. a Trastuzumab provides an ErbB3 escape route for the development of tumor resistance. When inhibiting ErbB2 signaling, ErbB3 expression will be upregulated to form new oncogenic complexes with ErbB2, especially when NRG-1 or another ErbB3 ligand is available to open its conformation. Consistently, both

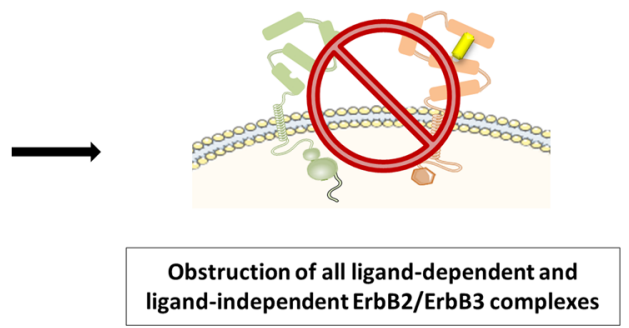

the upregulation of ErbB3 mRNA and the concentration of NRG-1 in tumor predict trastuzumab drug resistance. b Biparatopic ErbB2 trapping blocks all ligand-dependent and ligand-independent dimers of ErbB2. Pan-ErbB2 inhibition will stop PI3K/Akt signaling and avoid compensatory responses that lead to drug resistance 
negatively controlled by ErbB2 signaling, explaining why ErbB3 is upregulated during the suppression of ErbB2 signaling (Fig. 5a) [18]. Enhanced ErbB3 forms new oncogenic complexes with residually active ErbB2, which maintains oncogenic signaling and endorses anti-ErbB2 drug resistance [46]. This mechanism is especially intense when autocrine or paracrine NRG-1 is available in the tumor [45]. When NRG-1 binds to ErbB3, its conformation switches to the open conformation as such boosting dimerization of ErbB3 with the remaining active ErbB2. Thus, to avoid drug resistance, it seems compulsory to combine specific anti-ErbB2 therapy with anti-ErbB3 interventions, or to engineer bispecific anti-ErbB drugs that inhibit both ErbB2 and ErbB3 in a combined fashion. A recent study showed that trapping ErbB2 in a dimerizationincompetent state will also result into obstruction of all ligand-dependent and ligand-independent ErbB2/ErbB3 complexes (Fig. 5b). This pan-ErbB2 inhibition was shown to disarm all compensatory mechanisms and, therefore, to avoid the development of drug resistance [55].

A second challenge has been to avoid anti-ErbB2 cardiotoxicity. As explained above, ErbB2 signaling is important for cardiac physiology, especially in the conditions of cardiac overload and injury. However, as opposed to tumor cells, cardiac ErbB2 signaling is critically ligand (NRG-1)-dependent. This suggests that, as long as inhibitory anti-ErbB2 treatment does not interfere with liganddependent ErbB2 signaling, its cardiac profile may be safe [10].

\section{Trastuzumab: The first ErbB2-targeted drug, how does it work, where does it fail?}

\section{The clinical picture}

Trastuzumab $\left(\right.$ Herceptin $\left.^{\circledR}\right)$ is an effective anticancer treatment for ErbB2-overexpressing breast cancer in the adjuvant, neo-adjuvant, and metastatic settings. Adding the conventional chemotherapeutics increases the overall response to trastuzumab. In the adjuvant setting, based on several phase III trials, treatment with trastuzumab is given for 1 year. In the first human trials of trastuzumab, however, an unexpected cardiac toxicity was identified: $27 \%$ of patients receiving trastuzumab concurrently with anthracycline-containing chemotherapy developed either asymptomatic cardiomyopathy or clinical heart failure compared with $7 \%$ of patients receiving anthracycline chemotherapy alone [17, 49, 52]. Fortunately, in many cases, the cardiac dysfunction was asymptomatic, and further clinical trials indicated that in the absence of concomitant anthracycline treatment, the incidence of cardiac dysfunction was relatively low during treatment with trastuzumab, generally transient after the completion of therapy. In addition, the cardiac risks were outweighed overall by the potent anticancer effect of trastuzumab treatment [1].

Trastuzumab is a monoclonal antibody that binds to subdomain IV of ErbB2 (Fig. 6a). This binding disrupts ligand-independent ErbB2/ErbB3 interactions in ErbB2amplified cells and subsequently impedes PI3K/Akt activity $[23,28]$. However, it is yet uncertain whether this is the only mechanism responsible for trastuzumab's in vivo cancer-inhibiting actions. Other proposed mechanisms include increased endocytotic destruction of ErbB2, reduced shedding of the extracellular domain of ErB2 and immune activation by recruiting $\mathrm{Fc}$-competent immune effector cells, and other components of antibody-dependent cell-mediated cytotoxicity (ADCC) [23].

Due to the monoclonal humanized nature of trastuzumab, this antibody can only be studied on human cells. This explains why it has remained long unclear whether trastuzumab also interferes with NRG-1-dependent physiological ErbB signaling in the heart. Recently, however, using human fetal cardiomyocytes, Fedele and coworkers showed that trastuzumab, indeed, inhibited the formation of NRG-1-induced ErbB4/ErbB2 complexes [14]. This observation most likely explains why trastuzumab's cardiac toxicity primarily occurs when it is given simultaneously with anthracyclins. Indeed, NRG-1/ErbB signaling in the heart is part of a stress-activated compensatory system, playing a modest role in physiological conditions, but becoming indispensable in the injured heart, e.g., during ischemia or exposure to cardiotoxic agents, such as anthracyclins [21, 36].

Another disadvantage of trastuzumab's working mechanism is that it provides an ErbB3 escape route for the development of tumor resistance. Upon inhibition of ErbB2 signaling, ErbB3 expression is upregulated, and forms new oncogenic complexes with ErbB2, especially when NRG-1 or another ErbB3 ligand is available to open its conformation. Consistently, both the upregulation of ErbB3 mRNA and the concentration of NRG-1 in tumor predict trastuzumab drug resistance (Fig. 5) [46].

Accordingly, trastuzumab is an effective drug to inhibit malignant signaling in ErbB2 overexpressing tumor cells, but it has the disadvantage of (a) interfering with NRG-1/ ErbB2 signaling in the heart, which becomes harmful during co-treatment with antracyclines, and (b) allowing an ErbB3-dependent escape route for drug resistance through the upregulation of ErbB3 and formation of ligand-induced ErbB2/ErbB3 oncogenic complexes.

\section{How do next generation ErbB2 antagonists differ from trastuzumab?}

During the past decade, we have witnessed the introduction of several new drugs to target ErbB2 in cancer. These drugs 
A

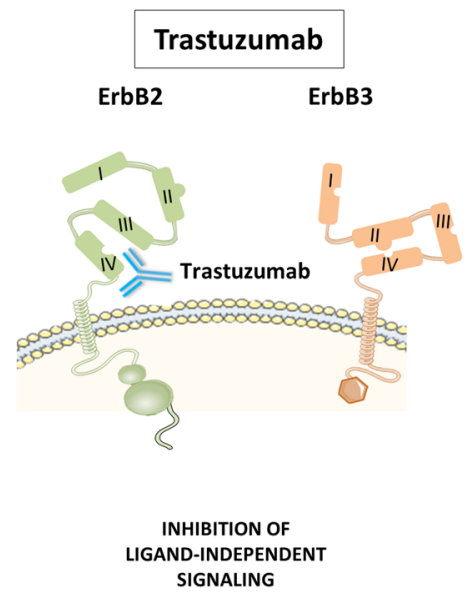

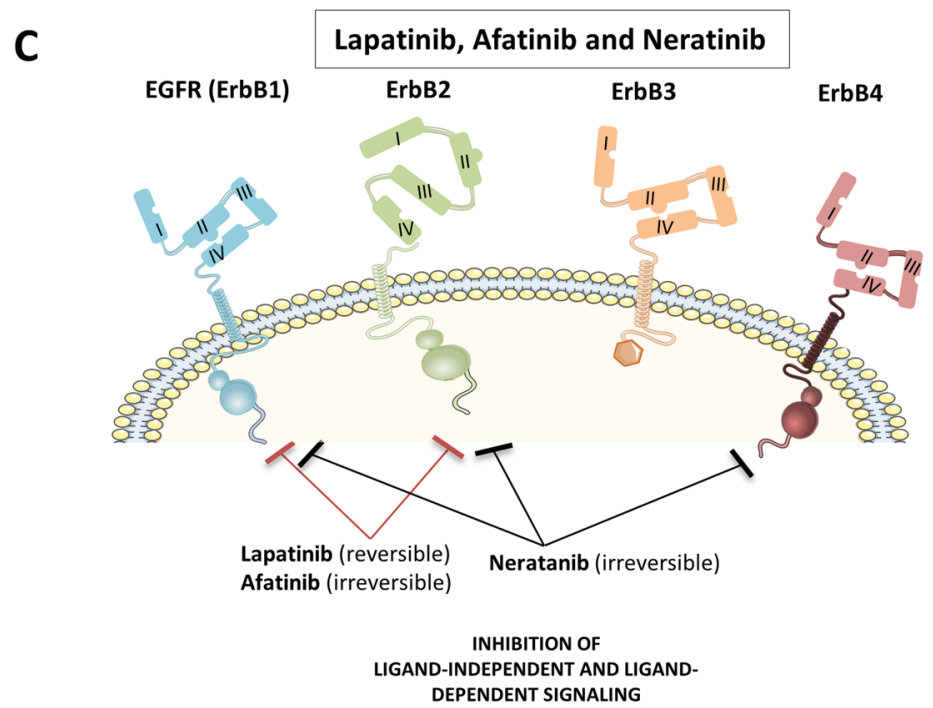

B

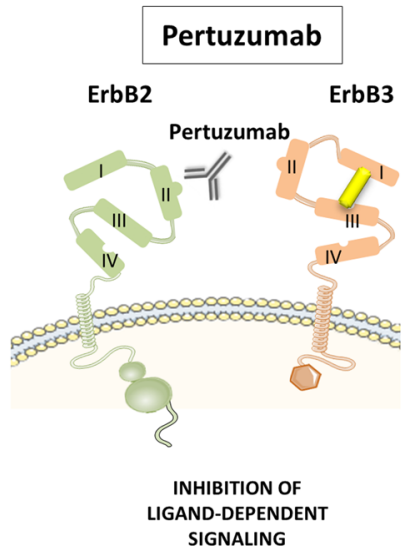

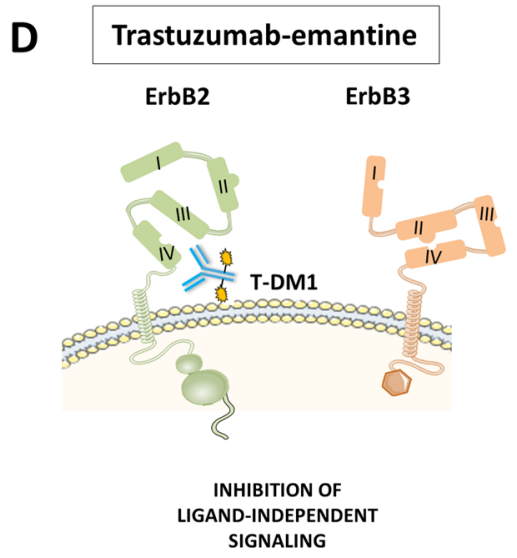

E

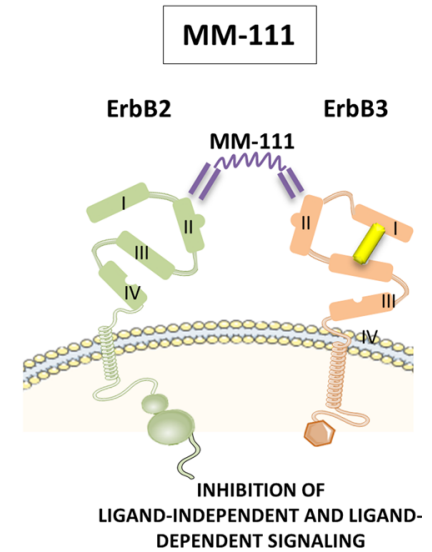

Fig. 6 Primary actions of current ErbB2 inhibitors. a Trastuzumab is a humanized monoclonal antibody to subdomain IV of ErBb2. This leads to the inhibition of ligand-independent ErbB2 signaling. b. Pertuzumab is a humanized monoclonal antibody to subdomain II of the dimerization arm of ErbB2. Pertuzumab leads to the inhibition of ligand-induced ErbB2 signaling. c. Lapatinib is a small molecule tyrosine kinase inhibitor of EGFR (ErbB1) and ErbB2. Afatinib and neratinib are two second-generation irreversible tyrosine kinase inhibitors. Afatinib is highly selective for EGFR/ErbB1 and

include new monoclonal antibodies against ErbB2 (pertuzumab, MM-111), oral small molecules ErbB tyrosine kinase inhibitors (lapatinib, afatinib, and neratinib), and an antibody-drug conjugate of trastuzumab combined with a cytotoxic agent, emtansine. Each of these molecules has a specific mode of action at the level of the ErbB receptors, hence influencing ligand-dependent and ligand-independent ErbB signaling in a unique way (Fig. 6). Specific activity profiles allow predicting their effect on tumor growth, the potential development of drug resistance, and their interference with physiological NRG-1-induced ErbB signaling in the heart and other organs. In the next paragraphs, we have compiled these profiles, and summarized them in Table 4.
ErbB2, whereas neratinib also inhibits ErbB4. Tyrosine kinase activity is blocked independently of whether this activity is ligandinduced or not. d Trastuzumab-emtansine is an antibody conjugate consisting of the monoclonal antibody trastuzumab linked to cyctotoxic agent emtansine, an antimicrotubule drug. e MM-111 is a bispecific antibody and polypeptide fusion protein of two human $\mathrm{scFv}$ antibodies linked to modified human serum albumin. MM-111 forms a trimeric complex with ErbB2 and ErbB3, inhibiting liganddependent ErbB2 and ErbB3 signaling

\section{Pertuzumab}

\section{The clinical picture}

The combination of pertuzumab plus trastuzumab plus docetaxel, as compared with placebo plus trastuzumab plus docetaxel, when used as the first-line treatment for ErbB2positive metastatic breast cancer, significantly prolongs progression-free survival. In the phase III randomized, double-blind, multinational CLEOPATRA trial, pertuzumab plus trastuzumab did not increase cardiac toxic effects [54]. Pertuzumab has not been tested in co-administration with anthracyclins. 
Table 4 Action of different ErbB2 antagonist on cancer cells and on ligand (NRG-1)-induced signaling and on cardiac function

\begin{tabular}{|c|c|c|c|c|}
\hline \multirow[t]{2}{*}{ Drug } & \multicolumn{2}{|l|}{ Tumor cell } & \multicolumn{2}{|l|}{ Cardiomyocyte } \\
\hline & Anticancer mechanism & $\begin{array}{l}\text { Secondary } \\
\text { Resistance }\end{array}$ & Effect on NRG-1 signaling & Cardiotoxicity \\
\hline Trastuzumab & $\begin{array}{l}\text { Inhibition of ErbB2/ErbB3 } \\
\text { dimerization by binding } \\
\text { domain IV of the ErbB2 } \\
\text { receptor }\end{array}$ & Yes & $\begin{array}{l}\text { Inhibits heterotypic ErbB2/ } \\
\text { ErbB4 signaling, but not } \\
\text { homotypic ErbB4/ErbB4 } \\
\text { signaling }\end{array}$ & $\begin{array}{l}\text { Tastuzumab monotherapy: } \\
{[49,53] 7 \%} \\
\text { Trastuzumab with } \\
\text { anthracyclines: [52] } 27 \%\end{array}$ \\
\hline Pertuzumab & $\begin{array}{l}\text { Inhibition of ErBb2/ErbB3 } \\
\text { dimerization by binding } \\
\text { domain II of the ErbB2 } \\
\text { receptor }\end{array}$ & No & $\begin{array}{l}\text { Inhibits heterotypic ErbB2/ } \\
\text { ErbB4 signaling, but not } \\
\text { homotypic ErbB4/ErbB4 } \\
\text { signaling }\end{array}$ & $\begin{array}{l}\text { Pertuzumab monotherapy: } \\
\text { [32] }<7 \%\end{array}$ \\
\hline Lapatinib & $\begin{array}{l}\text { Reversible tyrosine kinase } \\
\text { inhibitor of EGFR/ErbB1 } \\
\text { and ErbB2 }\end{array}$ & Yes [8] & $\begin{array}{l}\text { Inhibits heterotypic ErbB2/ } \\
\text { ErbB4 signaling, but not } \\
\text { homotypic ErbB4/ErbB4 } \\
\text { signaling }\end{array}$ & $\begin{array}{l}\text { Lapatinib monotherapy: } \\
{[43]<2 \%}\end{array}$ \\
\hline Neratinib & $\begin{array}{l}\text { Irreversible tyrosine kinase } \\
\text { inhibitor of EGFR/ErbB1, } \\
\text { ErbB2 and ErbB4 }\end{array}$ & Unknown & $\begin{array}{l}\text { Inhibits heterotypic ErbB2/ } \\
\text { ErbB4 signaling and } \\
\text { potentially homotypic } \\
\text { ErbB4/ErbB4 signaling }\end{array}$ & None reported $[4,48]$ \\
\hline Afatinib & $\begin{array}{l}\text { Irreversible tyrosine kinase } \\
\text { inhibitor of EGFR/ErbB1 } \\
\text { and ErbB2 }\end{array}$ & Unknown & $\begin{array}{l}\text { Inhibits heterotypic ErbB2/ } \\
\text { ErbB4 signaling, but not } \\
\text { homotypic ErbB4/ErbB4 }\end{array}$ & None reported $[35,60]$ \\
\hline $\begin{array}{l}\text { Trastuzumab- } \\
\text { emtansine } \\
\text { (T-DM1) }\end{array}$ & $\begin{array}{l}\text { Trastuzumab activity } \\
\text { combined with } \\
\text { intracellular delivery of a } \\
\text { microtubule } \\
\text { depolymerisation agent } \\
\text { (emtansine) }\end{array}$ & Unknown & $\begin{array}{l}\text { Inhibits heterotypic ErbB2/ } \\
\text { ErbB4 signaling, but not } \\
\text { homotypic ErbB4/ErbB4 } \\
\text { signaling }\end{array}$ & $\begin{array}{l}\text { T-DM1 monotherapy: [57] } \\
<2 \%\end{array}$ \\
\hline MM-111 & $\begin{array}{l}\text { A bispecific molecule } \\
\text { targeting the ErbB2/ } \\
\text { ErbB3 heterodimer, } \\
\text { forming an inactive } \\
\text { complex }\end{array}$ & Unknown & $\begin{array}{l}\text { No binding in the heart } \\
\text { given absence of ErbB2/ } \\
\text { ErbB3 heterodimers }\end{array}$ & None \\
\hline
\end{tabular}

Pertuzumab is a monoclonal antibody binding to subdomain II of ErbB2, hence, interfering specifically with ligand-induced ErbB2 dimerization (Fig. 6b) [10]. This working mechanism makes it a perfect drug to be combined with trastuzumab, as it will complementary inhibit the formation of ligand-induced ErbB2/ErbB3 oncogenic complexes arising after the upregulation of ErbB3 by trastuzumab [28]. This phenomenon most likely explains the success of the combination of trastuzumab and pertuzmab in the clinic: a prolonged survival of patients with metastatic breast cancer when pertuzumab was added to a treatment with trastuzumab and anthracyclines [7].

In contrast to trastuzumab, pertuzumab will also interfere with physiological ligand-induced ErbB2 signaling and as such potentially abrogate the protective actions of NRG-1 in the heart [28]. In fact, ErbB2 signaling in nonamplified ErbB2 cells may be abrogated more efficiently than in tumor cells, given the lower amount of ErbB2 copies. However, pertuzumab does not impede ligand-induced signaling through ErbB4 homodimers or through
ErbB4/ErbB3 heterodimers. It seems plausible that in the presence of pertuzumab and a reduced availability of ErbB2's dimerization arms, physiological NRG-1 signaling shifts towards ErbB2-independent signaling. Pertuzumab may thus merely modify but not inhibit physiological ErbB signaling activity. These phenomena may explain why in clinical trials, pertuzumab has emerged as a safe drug, with little or no cardiac toxicity.

\section{Lapatinib}

\section{The clinical picture}

Lapatinib is generally reserved for the late-stage treatment, and only in combination with capecitabine for ErbB2positive breast cancer in women, whose cancer has progressed following previous chemotherapy with anthracycline, taxanes, and trastuzumab. In combination with capecitabine, reversible decreases of left ventricular function occur [5]. 
Lapatinib is a small molecule intracellular and reversible ErbB2- and EGFR/ErbB1 tyrosine kinase inhibitor (Fig. 6c) [10]. As such, compared with trastuzumab, lapatinib has the advantage of inhibiting the phosphorylation of ErbB3 by ErbB2 in the oncogenic complex, independently of whether this complex was formed in a liganddependent or independent way. Hence, single treatment with lapatinib leaves little room for the development of drug resistance through ligand-induced ErbB2/ErbB3 oncogenic complexes, thereby mimicking the combination of trastuzumab plus pertuzumab. Nevertheless, recent studies indicate that ErbB3 is upregulated in lapatinibtreated cells and that it may still form ErbB2/ErbB3 complexes with residually active ErbB2 [38].

With regard to its effect on physiological NRG-1/ErbB signaling, lapatinib clearly abrogates ligand-induced ErbB2 signaling, hence potentially interfering with NRG-1-induced signaling. Similarly, as for pertuzumab, however, lapatinib should not interfere with ligand-induced ErbB4/ ErbB4 homotypic signaling or through ErbB4/ErbB3 heterotypic signaling. This may explain why lapatinib has emerged as a drug, with little or no cardiac toxicity [50].

Afatinib and neratinib are two second-generation irreversible tyrosine kinase inhibitors. Afatinib is highly selective for EGFR/ErbB1 and ErbB2, whereas neratinib also inhibits ErbB4, carrying the risk of block both homotypic and heterotypic signaling (Fig. 6c). No significant cardiac dysfunction in phase I and II trials have been reported for afatinib and neratinib. These early cardiac safety data are promising [50].

\section{Trastuzumab-emtansine}

Trastuzumab-emtansine (also known as T-DM1) is an antibody conjugate consisting of the monoclonal antibody trastuzumab linked to cyctotoxic agent emtansine (Fig. 6d). Trastuzumab targets ErbB2-positive tumors, whereas emtansine is a highly potent antimicrotubule drug [29]. This toxic effect is restricted to ErbB2-expressing cells that result in very little neuropathy and no hair loss [11]. T-DM1 has a better overall safety profile compared with trastuzumab. No significant cardiotoxicity was observed with T-DM1 in patients, previously treated with trastuzumab and a taxane [24]. Obviously, T-DM1 has never been tested in treatment schedules that co-administrated anthracyclins and T-DM1.

\section{MM-111}

MM-111 is a new bispecific antibody and polypeptide fusion protein of two human $\mathrm{scFv}$ antibodies linked to modified human serum albumin (Fig. 6e). The resulting molecule, MM-111, forms a trimeric complex with ErbB2 and ErbB3, inhibiting ErbB3 signaling and showing antitumor activity in preclinical models that are dependent on ErbB2 overexpression [38]. By its design, MM-111 blocks the activity of ligand-dependent and ligand-independent ErbB2/ErbB3 complexes in tumor cells, hence, recapitulating the effect of combining trastuzumab and pertuzumab or lapatanib, albeit in a completely different manner. A recent study demonstrated that MM-111 inhibition of ligand-activated ErbB3 phosphorylation is superior to pertuzumab, and that the combination of MM-111 with trastuzumab more effectively inhibits tumor cell growth than pertuzumab plus trastuzumab [38]. The underlying reason is that pertuzumab merely indirectly inhibits ErbB3 activation by precluding ErbB2 dimerization. In tumor cells with a high number of ErbB2, inhibition of ErbB2 by pertuzumab may be incomplete. By contrast, MM-111 inactivates ErbB3 in a direct way.

A major advantage of MM-111 is its specific binding to ErbB2/ErbB3 complexes. Since these complexes are absent or at least of minor abundance and/or physiological importance in the heart, it is very unlikely that MM-111 interferes with the physiological function of NRG-1 in the heart. Accordingly, at least from this perspective, the cardiotoxic profile of MM-111 should be safe.

\section{Conclusions}

The crucial position of ErbB2 at the cross road between cancer and heart failure has made it an attractive therapeutic target in both oncology and cardiology. Growing knowledge of ErbB2 signaling as well as smart drug design has gradually led to the development of therapeutics to target ErbB2 signaling in the right cell type, for safe use in cancer and heart failure. Molecules, such as bivalent NRG1 or MM-111, are exemplary for how a combination of a detailed understanding of biology and smart drug design can lead to fascinating progress in a complex medical field. Further clinical introduction of these drugs is ongoing and will tell whether these drugs can live up to the expectations.

\section{Compliance with ethical standards}

Conflicts of interest None declared.

Open Access This article is distributed under the terms of the Creative Commons Attribution 4.0 International License (http://crea tivecommons.org/licenses/by/4.0/), which permits unrestricted use, distribution, and reproduction in any medium, provided you give appropriate credit to the original author(s) and the source, provide a link to the Creative Commons license, and indicate if changes were made. 


\section{References}

1. Bellinger AM, Arteaga CL, Force T, Humphreys BD, Demetri GD, Druker BJ, Moslehi JJ (2015) Cardio-oncology: how new targeted cancer therapies and precision medicine can inform cardiovascular discovery. Circulation 132:2248-2258. doi:10. 1161/circulationaha.115.010484

2. Bersell K, Arab S, Haring B, Kuhn B (2009) Neuregulin1/ErbB4 signaling induces cardiomyocyte proliferation and repair of heart injury. Cell 138:257-270. doi:10.1016/j.cell.2009.04.060

3. Bian Y, Sun M, Silver M, Ho KK, Marchionni MA, Caggiano AO, Stone JR, Amende I, Hampton TG, Morgan JP, Yan X (2009) Neuregulin-1 attenuated doxorubicin-induced decrease in cardiac troponins. Am J Physiol Heart Circ Physiol 297:H1974H1983. doi:10.1152/ajpheart.01010.2008

4. Burstein HJ, Sun Y, Dirix LY, Jiang Z, Paridaens R, Tan AR, Awada A, Ranade A, Jiao S, Schwartz G, Abbas R, Powell C, Turnbull K, Vermette J, Zacharchuk C, Badwe R (2010) Neratinib, an irreversible ErbB receptor tyrosine kinase inhibitor, in patients with advanced ErbB2-positive breast cancer. J Clin Oncol 28:1301-1307. doi:10.1200/jco.2009.25.8707

5. Cameron D, Casey M, Press M, Lindquist D, Pienkowski T, Romieu CG, Chan S, Jagiello-Gruszfeld A, Kaufman B, Crown J, Chan A, Campone M, Viens P, Davidson N, Gorbounova V, Raats JI, Skarlos D, Newstat B, Roychowdhury D, Paoletti P, Oliva C, Rubin S, Stein S, Geyer CE (2008) A phase III randomized comparison of lapatinib plus capecitabine versus capecitabine alone in women with advanced breast cancer that has progressed on trastuzumab: updated efficacy and biomarker analyses. Breast Cancer Res Treat 112:533-543. doi:10.1007/ s10549-007-9885-0

6. Camprecios G, Lorita J, Pardina E, Peinado-Onsurbe J, Soley M, Ramirez I (2011) Expression, localization, and regulation of the neuregulin receptor ErbB3 in mouse heart. J Cell Physiol 226:450-455. doi: $10.1002 /$ jcp. 22354

7. Cortes J, Fumoleau P, Bianchi GV, Petrella TM, Gelmon K, Pivot X, Verma S, Albanell J, Conte P, Lluch A, Salvagni S, Servent V, Gianni L, Scaltriti M, Ross GA, Dixon J, Szado T, Baselga J (2012) Pertuzumab monotherapy after trastuzumab-based treatment and subsequent reintroduction of trastuzumab: activity and tolerability in patients with advanced human epidermal growth factor receptor 2-positive breast cancer. J Clin Oncol 30:1594-1600. doi:10.1200/jco.2011.37.4207

8. D'Amato V, Raimondo L, Formisano L, Giuliano M, De Placido S, Rosa R, Bianco R (2015) Mechanisms of lapatinib resistance in HER2-driven breast cancer. Cancer Treat Rev 41:877-883. doi:10.1016/j.ctrv.2015.08.001

9. D'Uva G, Aharonov A, Lauriola M, Kain D, Yahalom-Ronen Y, Carvalho $\mathrm{S}$, Weisinger $\mathrm{K}$, Bassat E, Rajchman D, Yifa O, Lysenko M, Konfino T, Hegesh J, Brenner O, Neeman M, Yarden Y, Leor J, Sarig R, Harvey RP, Tzahor E (2015) ERBB2 triggers mammalian heart regeneration by promoting cardiomyocyte dedifferentiation and proliferation. Nat Cell Biol 17:627-638. doi:10.1038/ncb3149, http://www.nature.com/ncb/journal/v17/ n5/abs/ncb3149.html\#supplementary-information

10. De Keulenaer GW, Doggen K, Lemmens K (2010) The vulnerability of the heart as a pluricellular paracrine organ: lessons from unexpected triggers of heart failure in targeted ErbB2 anticancer therapy. Circ Res 106:35-46. doi:10.1161/circresaha.109.205906

11. Eisenstein M (2015) Medicine: eyes on the target. Nature 527:S110-S112. doi:10.1038/527S110a

12. Ennequin G, Boisseau N, Caillaud K, Chavanelle V, Etienne M, Li X, Sirvent P (2015) Neuregulin 1 Improves Glucose Tolerance in db/db Mice. PLoS One 10:e130568. doi:10.1371/journal. pone. 0130568
13. Fang SJ, Wu XS, Han ZH, Zhang XX, Wang CM, Li XY, Lu LQ, Zhang JL (2010) Neuregulin-1 preconditioning protects the heart against ischemia/reperfusion injury through a PI3K/Akt-dependent mechanism. Chin Med J (Engl) 123:3597-3604

14. Fedele C, Riccio G, Malara AE, D'Alessio G, De Lorenzo C (2012) Mechanisms of cardiotoxicity associated with ErbB2 inhibitors. Breast Cancer Res Treat 134:595-602. doi:10.1007/ s10549-012-2103-8

15. Galindo CL, Kasasbeh E, Murphy A, Ryzhov S, Lenihan S, Ahmad FA, Williams P, Nunnally A, Adcock J, Song Y, Harrell FE, Tran TL, Parry TJ, Iaci J, Ganguly A, Feoktistov I, Stephenson MK, Caggiano AO, Sawyer DB, Cleator JH (2014) Anti-remodeling and anti-fibrotic effects of the neuregulin-1beta glial growth factor 2 in a large animal model of heart failure. J Am Heart Assoc 3:e000773. doi:10.1161/jaha.113.000773

16. Ganapathy B, Nandhagopal N, Polizzotti BD, Bennett D, Asan A, Wu Y, Kuhn B (2016) Neuregulin-1 Administration Protocols Sufficient for Stimulating Cardiac Regeneration in Young Mice Do Not Induce Somatic, Organ, or Neoplastic Growth. PLoS One 11:e0155456. doi:10.1371/journal.pone.0155456

17. Gao R, Zhang J, Cheng L, Wu X, Dong W, Yang X, Li T, Liu X, Xu Y, Li X, Zhou M (2010) A Phase II, randomized, doubleblind, multicenter, based on standard therapy, placebo-controlled study of the efficacy and safety of recombinant human neuregulin-1 in patients with chronic heart failure. J Am Coll Cardiol 55:1907-1914. doi:10.1016/j.jacc.2009.12.044

18. Garrett JT, Olivares MG, Rinehart C, Granja-Ingram ND, Sanchez V, Chakrabarty A, Dave B, Cook RS, Pao W, McKinely E, Manning HC, Chang J, Arteaga CL (2011) Transcriptional and posttranslational up-regulation of HER3 (ErbB3) compensates for inhibition of the HER2 tyrosine kinase. Proc Natl Acad Sci USA 108:5021-5026. doi:10.1073/pnas.1016140108

19. Gu X, Liu X, Xu D, Li X, Yan M, Qi Y, Yan W, Wang W, Pan J, Xu Y, Xi B, Cheng L, Jia J, Wang K, Ge J, Zhou M (2010) Cardiac functional improvement in rats with myocardial infarction by up-regulating cardiac myosin light chain kinase with neuregulin. Cardiovasc Res 88:334-343. doi:10.1093/cvr/cvq223

20. Guo YF, Zhang XX, Liu Y, Duan HY, Jie BZ, Wu XS (2012) Neuregulin-1 attenuates mitochondrial dysfunction in a rat model of heart failure. Chin. Med. J. (Engl) 125:807-814

21. Hedhli N, Huang Q, Kalinowski A, Palmeri M, Hu X, Russell RR, Russell KS (2011) Endothelium-derived neuregulin protects the heart against ischemic injury. Circulation 123:2254-2262. doi:10.1161/circulationaha.110.991125

22. Holbro T, Beerli RR, Maurer F, Koziczak M, Barbas CF 3rd, Hynes NE (2003) The ErbB2/ErbB3 heterodimer functions as an oncogenic unit: ErbB2 requires ErbB3 to drive breast tumor cell proliferation. Proc Natl Acad Sci USA 100:8933-8938. doi:10. 1073/pnas. 1537685100

23. Hudis CA (2007) Trastuzumab-mechanism of action and use in clinical practice. $\mathrm{N}$ Engl J Med 357:39-51. doi:10.1056/ NEJMra043186

24. Hurvitz SA, Kakkar R (2012) The potential for trastuzumab emtansine in human epidermal growth factor receptor 2 positive metastatic breast cancer: latest evidence and ongoing studies. Ther Adv Med Oncol 4:235-245. doi:10.1177/1758834012451205

25. Jabbour A, Hayward CS, Keogh AM, Kotlyar E, McCrohon JA, England JF, Amor R, Liu X, Li XY, Zhou MD, Graham RM, Macdonald PS (2011) Parenteral administration of recombinant human neuregulin-1 to patients with stable chronic heart failure produces favourable acute and chronic haemodynamic responses. Eur J Heart Fail 13:83-92. doi:10.1093/eurjhf/hfq152

26. Jay SM, Kurtagic E, Alvarez LM, de Picciotto S, Sanchez E, Hawkins JF, Prince RN, Guerrero Y, Treasure CL, Lee RT, Griffith LG (2011) Engineered bivalent ligands to bias ErbB 
receptor-mediated signaling and phenotypes. J Biol Chem 286:27729-27740. doi:10.1074/jbc.M111.221093

27. Jay SM, Murthy AC, Hawkins JF, Wortzel JR, Steinhauser ML, Alvarez LM, Gannon J, Macrae CA, Griffith LG, Lee RT (2013) An engineered bivalent neuregulin protects against doxorubicininduced cardiotoxicity with reduced proneoplastic potential. Circulation 128:152-161. doi:10.1161/circulationaha.113.002203

28. Junttila TT, Akita RW, Parsons K, Fields C, Lewis Phillips GD, Friedman LS, Sampath D, Sliwkowski MX (2009) Ligand-independent HER2/HER3/PI3K complex is disrupted by trastuzumab and is effectively inhibited by the PI3K inhibitor GDC-0941. Cancer Cell 15:429-440. doi:10.1016/j.ccr.2009.03.020

29. Lambert JM, Chari RV (2014) Ado-trastuzumab Emtansine (TDM1): an antibody-drug conjugate (ADC) for HER2-positive breast cancer. J Med Chem 57:6949-6964. doi:10.1021/ jm500766w

30. Lemmens K, Doggen K, De Keulenaer GW (2011) Activation of the neuregulin/ErbB system during physiological ventricular remodeling in pregnancy. Am J Physiol Heart Circ Physiol 300:H931-H942. doi:10.1152/ajpheart.00385.2010

31. Lemmens K, Doggen K, De Keulenaer GW (2007) Role of neuregulin-1/ErbB signaling in cardiovascular physiology and disease: implications for therapy of heart failure. Circulation 116:954-960. doi:10.1161/circulationaha.107.690487

32. Lenihan D, Suter T, Brammer M, Neate C, Ross G, Baselga J (2012) Pooled analysis of cardiac safety in patients with cancer treated with pertuzumab. Ann Oncol 23:791-800. doi:10.1093/ annonc/mdr294

33. Li B, Zheng Z, Wei Y, Wang M, Peng J, Kang T, Huang X, Xiao J, Li Y, Li Z (2011) Therapeutic effects of neuregulin-1 in diabetic cardiomyopathy rats. Cardiovasc Diabetol 10:69. doi:10. 1186/1475-2840-10-69

34. Li J, Gu XH, Duan JC, Zeng L, Li Y, Wang L (2007) [Effects of recombined human neuregulin on the contractibility of cardiac muscles of rhesus monkeys with pacing-induced heart failure]. Sichuan da xue xue bao. Yi xue ban = Journal of Sichuan University. Med Sci Edn 38:105-108

35. Lin NU, Winer EP, Wheatley D, Carey LA, Houston S, Mendelson D, Munster P, Frakes L, Kelly S, Garcia AA, Cleator S, Uttenreuther-Fischer M, Jones H, Wind S, Vinisko R, Hickish T (2012) A phase II study of afatinib (BIBW 2992), an irreversible ErbB family blocker, in patients with HER2-positive metastatic breast cancer progressing after trastuzumab. Breast Cancer Res Treat 133:1057-1065. doi:10.1007/s10549-012-2003-y

36. Liu FF, Stone JR, Schuldt AJ, Okoshi K, Okoshi MP, Nakayama M, Ho KK, Manning WJ, Marchionni MA, Lorell BH, Morgan JP, Yan X (2005) Heterozygous knockout of neuregulin-1 gene in mice exacerbates doxorubicin-induced heart failure. American journal of physiology. Heart and circulatory physiology 289:H660-H666. doi:10.1152/ajpheart.00268.2005

37. Liu X, Gu X, Li Z, Li X, Li H, Chang J, Chen P, Jin J, Xi B, Chen D, Lai D, Graham RM, Zhou M (2006) Neuregulin-1/erbB-activation improves cardiac function and survival in models of ischemic, dilated, and viral cardiomyopathy. J Am Coll Cardiol 48:1438-1447. doi:10.1016/j.jacc.2006.05.057

38. McDonagh CF, Huhalov A, Harms BD, Adams S, Paragas V, Oyama S, Zhang B, Luus L, Overland R, Nguyen S, Gu J, Kohli N, Wallace M, Feldhaus MJ, Kudla AJ, Schoeberl B, Nielsen UB (2012) Antitumor activity of a novel bispecific antibody that targets the ErbB2/ErbB3 oncogenic unit and inhibits heregulininduced activation of ErbB3. Mol Cancer Ther 11:582-593. doi:10.1158/1535-7163.mct-11-0820

39. Mendes-Ferreira P, De Keulenaer GW, Leite-Moreira AF, BrasSilva C (2013) Therapeutic potential of neuregulin-1 in cardiovascular disease. Drug Discovery Today 18:836-842. doi:10. 1016/j.drudis.2013.01.010
40. Mendes-Ferreira P, Maia-Rocha C, Adao R, Mendes MJ, SantosRibeiro D, Alves BS, Cerqueira RJ, Castro-Chaves P, Lourenco AP, De Keulenaer GW, Leite-Moreira AF, Bras-Silva C (2016) Neuregulin-1 improves right ventricular function and attenuates experimental pulmonary arterial hypertension. Cardiovasc Res 109:44-54. doi:10.1093/cvr/cvv244

41. Odiete O, Hill MF, Sawyer DB (2012) Neuregulin in cardiovascular development and disease. Circ Res 111:1376-1385. doi:10.1161/circresaha.112.267286

42. Parodi EM, Kuhn B (2014) Signalling between microvascular endothelium and cardiomyocytes through neuregulin. Cardiovasc Res 102:194-204. doi:10.1093/cvr/cvu021

43. Perez EA, Koehler M, Byrne J, Preston AJ, Rappold E, Ewer MS (2008) Cardiac safety of lapatinib: pooled analysis of 3689 patients enrolled in clinical trials. Mayo Clin Proc 83:679-686. doi: $10.4065 / 83.6 .679$

44. Polizzotti BD, Ganapathy B, Walsh S, Choudhury S, Ammanamanchi N, Bennett DG, dos Remedios CG, Haubner BJ, Penninger JM, Kuhn B (2015) Neuregulin stimulation of cardiomyocyte regeneration in mice and human myocardium reveals a therapeutic window. Science translational medicine 7:281ra245 doi:10.1126/scitranslmed.aaa5171

45. Ritter CA, Perez-Torres M, Rinehart C, Guix M, Dugger T, Engelman JA, Arteaga CL (2007) Human breast cancer cells selected for resistance to trastuzumab in vivo overexpress epidermal growth factor receptor and ErbB ligands and remain dependent on the ErbB receptor network. Clin Cancer Res 13:4909-4919. doi:10.1158/1078-0432.ccr-07-0701

46. Schoeberl B, Pace EA, Fitzgerald JB, Harms BD, Xu L, Nie L, Linggi B, Kalra A, Paragas V, Bukhalid R, Grantcharova V, Kohli N, West KA, Leszczyniecka M, Feldhaus MJ, Kudla AJ, Nielsen UB (2009) Therapeutically targeting ErbB3: a key node in ligand-induced activation of the ErbB receptor-PI3K axis. Sci Signal 2:ra31 doi:10.1126/scisignal.2000352

47. Schulze WX, Deng L, Mann M (2005) Phosphotyrosine interactome of the ErbB-receptor kinase family. Mol Syst Biol 1(2005):0008

48. Segovia-Mendoza M, Gonzalez-Gonzalez ME, Barrera D, Diaz L, Garcia-Becerra R (2015) Efficacy and mechanism of action of the tyrosine kinase inhibitors gefitinib, lapatinib and neratinib in the treatment of HER2-positive breast cancer: preclinical and clinical evidence. Am J Cancer Res 5:2531-2561

49. Seidman A, Hudis C, Pierri MK, Shak S, Paton V, Ashby M, Murphy M, Stewart SJ, Keefe D (2002) Cardiac dysfunction in the trastuzumab clinical trials experience. J Clin Oncol 20:1215-1221

50. Sendur MA, Aksoy S, Altundag K (2013) Cardiotoxicity of novel HER2-targeted therapies. Curr Med Res Opin 29:1015-1024. doi: $10.1185 / 03007995.2013 .807232$

51. Sergina NV, Rausch M, Wang D, Blair J, Hann B, Shokat KM, Moasser MM (2007) Escape from HER-family tyrosine kinase inhibitor therapy by the kinase-inactive HER3. Nature 445:437-441. doi:10.1038/nature05474

52. Slamon DJ, Leyland-Jones B, Shak S, Fuchs H, Paton V, Bajamonde A, Fleming T, Eiermann W, Wolter J, Pegram M, Baselga J, Norton L (2001) Use of chemotherapy plus a monoclonal antibody against HER2 for metastatic breast cancer that overexpresses HER2. N Engl J Med 344:783-792. doi:10.1056/ nejm200103153441101

53. Suter TM, Procter M, van Veldhuisen DJ, Muscholl M, Bergh J, Carlomagno C, Perren T, Passalacqua R, Bighin C, Klijn JG, Ageev FT, Hitre E, Groetz J, Iwata H, Knap M, Gnant M, Muehlbauer S, Spence A, Gelber RD, Piccart-Gebhart MJ (2007) Trastuzumab-associated cardiac adverse effects in the herceptin adjuvant trial. J Clin Oncol 25:3859-3865. doi:10.1200/jco.2006. 09.1611 
54. Swain SM, Baselga J, Kim SB, Ro J, Semiglazov V, Campone M, Ciruelos E, Ferrero JM, Schneeweiss A, Heeson S, Clark E, Ross G, Benyunes MC, Cortes J (2015) Pertuzumab, trastuzumab, and docetaxel in HER2-positive metastatic breast cancer. N Engl J Med 372:724-734. doi:10.1056/NEJMoa1413513

55. Tamaskovic R, Schwill M, Nagy-Davidescu G, Jost C, Schaefer DC, Verdurmen WP, Schaefer JV, Honegger A, Pluckthun A (2016) Intermolecular biparatopic trapping of ErbB2 prevents compensatory activation of PI3K/AKT via RAS-p110 crosstalk. Nat Commun 7:11672. doi:10.1038/ncomms11672

56. Vandekerckhove L, Vermeulen Z, Liu ZZ, Boimvaser S, Patzak A, Segers VF, De Keulenaer GW (2016) Neuregulin-1 attenuates development of nephropathy in a type 1 diabetes mouse model with high cardiovascular risk. Am J Physiol Endocrinol Metab. doi:10.1152/ajpendo.00432.2015

57. Verma S, Miles D, Gianni L, Krop IE, Welslau M, Baselga J, Pegram M, Oh DY, Dieras V, Guardino E, Fang L, Lu MW, Olsen S, Blackwell K (2012) Trastuzumab emtansine for HER2positive advanced breast cancer. N Engl J Med 367:1783-1791. doi:10.1056/NEJMoa1209124
58. Xiao J, Li B, Zheng Z, Wang M, Peng J, Li Y, Li Z (2012) Therapeutic effects of neuregulin-1 gene transduction in rats with myocardial infarction. Coron Artery Dis 23:460-468. doi:10. 1097/MCA.0b013e32835877da

59. Xu G, Watanabe T, Iso Y, Koba S, Sakai T, Nagashima M, Arita S, Hongo S, Ota H, Kobayashi Y, Miyazaki A, Hirano T (2009) Preventive effects of heregulin-betal on macrophage foam cell formation and atherosclerosis. Circ Res 105:500-510. doi:10. 1161/circresaha.109.193870

60. Yap TA, Vidal L, Adam J, Stephens P, Spicer J, Shaw H, Ang J, Temple G, Bell S, Shahidi M, Uttenreuther-Fischer M, Stopfer P, Futreal A, Calvert H, de Bono JS, Plummer R (2010) Phase I trial of the irreversible EGFR and HER2 kinase inhibitor BIBW 2992 in patients with advanced solid tumors. J Clin Oncol 28:3965-3972. doi:10.1200/jco.2009.26.7278

61. Zhao YY, Sawyer DR, Baliga RR, Opel DJ, Han X, Marchionni MA, Kelly RA (1998) Neuregulins promote survival and growth of cardiac myocytes. Persistence of ErbB2 and ErbB4 expression in neonatal and adult ventricular myocytes. J Biol Chem 273:10261-10269 